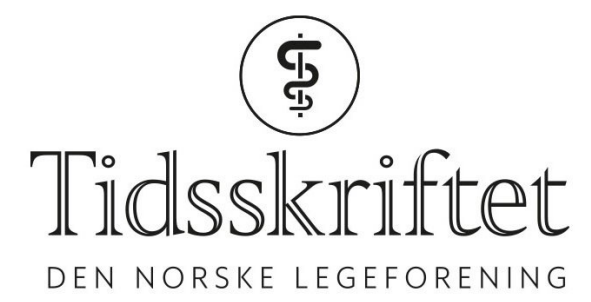

\title{
Retten til å delta i arbeidslivet
}

KOMMENTAR

\section{JON FISKE}

E-post: jon.fiske@nav.no

Jon Fiske er psykologspesialist i klinisk arbeidspsykologi og arbeids- og organisasjonspsykologi, avdelingsdirektør for Arbeid og helse i Nav Øst-Viken. Forfatteren har ikke oppgitt noen interessekonflikter.

I essayet «Hva skal til for å få flere i arbeid» publisert i Tidsskrift for Den norske legeforening 22.02.21, er Steinar Krokstad (professor i sosialmedisin) kritisk til NAV sin aktivitetsplikt (1).

Jeg forstår Krokstad sin kritikk av NAV sin aktivitetsplikt ved mottak av enkelte ytelser. Krav og plikt kan for mange virke lite motiverende sammenlignet med selvdrevne mål. Likevel kan det å leve opp til andres krav og plikter også virke tilfredsstillende. Vi har eksempelvis sett arbeidssøkere som har stått fram i media og uttalt at NAV sin aktivitetsplikt har virket positivt fordi de opplever det positivt å være i aktivitet, og kunne bidra og gi noe tilbake når de mottar en ytelse. Uansett er ikke NAV sin veiledningsmetodikk for samhandling med brukere basert på plikt, men myndiggjøring der personen utarbeider en aktivitetsplan basert på egne interesser og styrker.

Krokstad skriver at et ekskluderende arbeidsmarked er hovedårsaken til at ikke flere er i arbeid. Det er riktig at arbeidsgivere har en viktig rolle i å inkludere flere. Derfor er det positivt at flere arbeidsgivere bidrar i inkluderingsdugnaden og jobber sammen med NAV med jobbskaping for personer med helsemessige- og sammensatte utfordringer. Det er likevel mer sammensatte årsaker til at ikke flere er i arbeid enn et ekskluderende arbeidsmarked.

Krokstad peker på viktigheten av å møte mennesker med anerkjennelse og mulighet til å oppleve mestring og at dette bør bli et nytt faglig og vitenskapelig grunnlag for NAV. Som ansatt i NAV opplever jeg at vi nettopp har et slikt faglig og vitenskapelig grunnlag. Dette baserer seg på kunnskap om hva som bidrar til jobbmestring gjennom arbeidshåp og mestringstro.

Langvarig utenforskap der man forhindres fra å delta i arbeid og utdanning er forbundet med dårligere psykisk helse. Jeg synes Krokstad i for stor grad peker på NAV og arbeidsgivere som årsaken til utenforskap. NAV og arbeidsgivere er også avhengig av et godt samarbeid med helse, da helsemestring og jobbmestring er gjensidig knyttet sammen.

Jeg er enig med Krokstad i at de som står utenfor er avhengig av tilgjengelige mestringserfaringer. I tillegg er mestringstro avhengig av støtte og forventninger fra omgivelsene, og helsemestring.

Forskning viser at troen på jobbmestring, som er nært knyttet til arbeidshåp og mestringstro, er mer avgjørende for retur til jobb enn symptomnivå (2). Her er det 
avgjørende at sentrale aktører rundt personen som NAV, fastlege og arbeidsgiver også viser at de har tro og håp for personen det gjelder.

NAV sitt samarbeid med fastleger og behandlere er her svært viktig. NAV er avhengig av at fastleger og behandlere har arbeidsfokus og kartlegger arbeidsmuligheter på tross av funksjonsnedsettelse. Mange blir stående for lenge sykemeldt uten aktivitet og mister over tid troen på at de skal kunne komme tilbake i jobb. En samordnet plan med støtte fra NAV og fastlege kan være avgjørende for troen på jobbmestring. I tillegg må arbeidsgivere kunne tilrettelegge arbeidet slik at ansatte kan fungere i jobb på tross av helseplager.

Et godt samarbeid mellom NAV og helse er avgjørende for å kunne utvikle gode modeller for integrert jobb- og helsemestring. Vi kan i NAV vise til gode resultater med integrert jobbog helsemestring ved Senter for jobbmestring (3). Vi har også god erfaring med IPS- tiltak der jobbspesialister fra NAV bistår i behandlingsteam i helsetjenesten.

Jeg vil betrygge Krokstad med at NAV deler hans grunnleggende holdninger om å møte mennesker med anerkjennelse og fokus på ressurser og muligheter for jobbmestring. Men for at flere skal få muligheten til å delta i arbeidslivet må vi se på hvordan NAV, helse og arbeidsgivere sammen kan gi flere tro og håp på jobbmestring. Mange av de vi skal bistå har helseutfordringer som gjør det krevende å opprettholde arbeidshåpet alene.

Jeg vil utfordre leger til å se på hvordan vi kan samarbeide om å hindre utenforskap og inkludere flere i arbeid og skole. I stedet for å diskutere krav og plikt til å delta i arbeidslivet, bør vi sette søkelys på retten til å delta i arbeidslivet.

LITTERATUR:

1. Krokstad S. Hva skal til for å få flere i arbeid? Tidsskr Nor Legeforen 2021; 141. doi: 10.4045/tidsskr.20.076o. [PubMed][CrossRef]

2. Løvvik C, Shaw W, Øverland S et al. Expectations and illness perceptions as predictors of benefit recipiency among workers with common mental disorders: secondary analysis from a randomised controlled trial. BMJ Open 2014; 4: eoo4321. [PubMed][CrossRef]

3. Reme SE, Grasdal AL, Løvvik C et al. Work-focused cognitive-behavioural therapy and individual job support to increase work participation in common mental disorders: a randomised controlled multicentre trial. Occup Environ Med 2015; 72: 745-52. [PubMed][CrossRef]

Publisert: 28. juni 2021. Tidsskr Nor Legeforen. DOI: 10.4045/tidsskr.21.0468

(C) Tidsskrift for Den norske legeforening 2020. Lastet ned fra tidsskriftet.no 